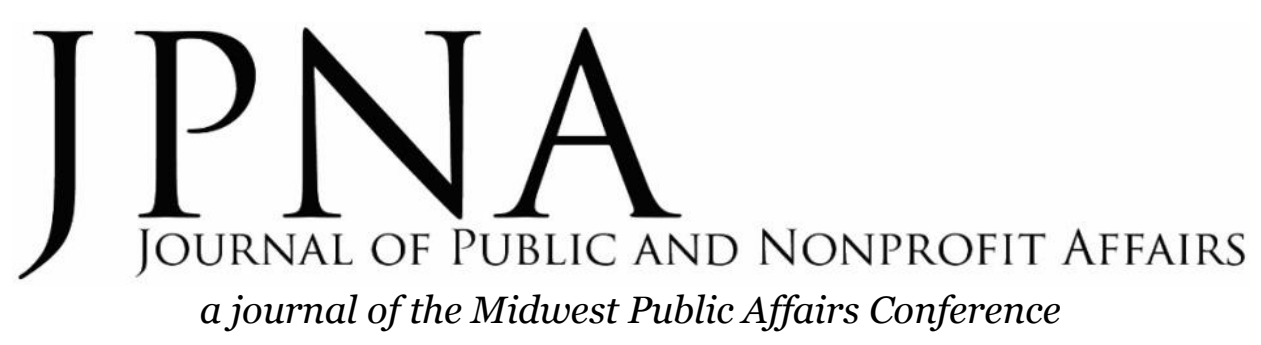

\title{
Summer 2021
}

Volume 7, Number 2

Editor's Introduction: Highlighting Strategies of the Nonprofit Sector

Deborah A. Carroll ............................................ 169

\section{Research Articles}

NPO/NGO Education in Public Administration in South Korea

Bok Gyo Jeong and Sung-Ju Kim . . . . . . . . . . . . . . . . . . . . . 173

The Role of Financial Burden in Nonprofit Sector Commitment

Kerry Kuenzi, Marlene Walk, and Amanda J. Stewart . . . . . . . . . . . . . . . . . 192

Group Type and Social Media Engagement Strategies in the EU: The Case of British Interest Groups on Facebook

Direnç Kanol and Müesser Nat

Nonprofit External Communications: General Management, Public Relations, or

Fundraising Tool?

Jiwon Suh, Trang Hoang, and Imane Hïal . . . . . . . . . . . . . . . 220

Conceptualizing and Measuring the Promotion of Nonprofit Organizations' Evidence Use by U.S. Social Service Funding Programs

Christopher S. Horne, John K. Brock, J. Kenzie Freeman, and Holly S. Odell . . 240

Does Gender Congruence Make a Difference in Female Members' Volunteering Behaviors?

Khaldoun AbouAssi . . . . . . . . . . . . . . . . . . . . . . . . . . . . . 264

\section{Social Equity}

Advancing Social Equity: Examining the Impact of Gender, Place, and Race on Criminal Justice Administration in Alabama

Regina Moorer..................................... 283

\section{Book Reviews}

The Public Affairs Faculty Manual: A Guide to the Effective Management of Public Affairs Programs Edited by Bruce McDonald, III and William Hatcher

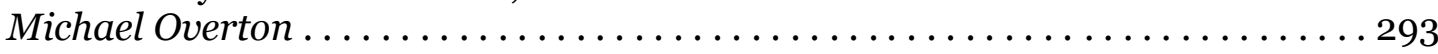

Achieving Social Equity: From Problems to Solutions by Mary E. Guy and Sean A. McCandless

Bruce D. McDonald, III . . 
